\title{
PATHOLOGY OF EXPLANTED CRYOPRESERVED ALLOGRAFT HEART VALVES: COMPARISON WITH AORTIC VALVES FROM ORTHOTOPIC HEART TRANSPLANTS
}

Richard N. Mitchell, MD, $\mathrm{PhD}^{\mathrm{a}}$

Richard A. Jonas, MD ${ }^{\mathrm{b}}$

Frederick J. Schoen, MD, $\mathrm{PhD}^{\mathrm{a}}$
Objective: We sought to determine the morphology, mechanisms of deterioration, cellular viability, extracellular matrix integrity, and the role of immune responses in the dysfunction of cryopreserved aortic and pulmonic valve allografts. Methods: We studied 33 explanted left-sided $(n=20)$ or right-sided $(n=13)$ cryopreserved human allograft heart valves explanted several hours to 9 years after operation, 14 nonimplanted allografts, and 16 aortic valves removed from transplanted allograft hearts 2 days to 4 years after operation. Analysis included gross inspection, radiography, light microscopy, electron microscopy, and immunohistochemical studies. $R e$ sults: Allografts implanted for more than 1 day had progressive collagen hyalinization and loss of normal structural complexity and cellularity, including endothelium and deep connective tissue cells. Inflammatory cells were generally minimal or absent in the allografts. Transmission electron microscopy of long-term cryopreserved allograft valves revealed no viable cells, focal calcification centered around dead cell remnants, and distorted but preserved collagen. In contrast, aortic valves from transplanted hearts showed remarkable structural preservation, including endothelium and abundant deep connective tissue cells; inflammatory infiltrates were generally mild and of no apparent deleterious consequence, including valves from patients who died of fatal rejection. Conclusions: Cryopreserved allografts are morphologically nonviable; their collagen is flattened but largely preserved. They are unlikely to grow, remodel, or exhibit active metabolic functions, and their usual degeneration cannot be attributed to immunologic responses. In contrast, aortic valves of transplanted hearts maintain near-normal overall architecture and cellularity and do not show apparent immunologic injury, even in the setting of fatal myocardial parenchymal rejection or graft arteriosclerosis. (J Thorac Cardiovasc Surg 1998;115:118-27)
A ortic or pulmonic valve allografts have exceptionally good hemodynamic profiles, a low incidence of thromboembolic complications without anticoagulation, and resistance to endocarditis. ${ }^{1-4}$ Although allograft valves were initially collected by

From the Department of Pathology, ${ }^{a}$ Brigham and Women's Hospital, Department of Cardiovascular Surgery, ${ }^{\mathrm{b}}$ Children's Hospital, and the Departments of Pathology and Surgery, ${ }^{\mathrm{b}}$ Harvard Medical School, Boston, Mass.

Received for publication March 6, 1997; revisions requested May 13, 1997; revisions received June 24, 1997; accepted for publication August 18, 1997.

Address for reprints: Frederick J. Schoen, MD, PhD, Department of Pathology, Brigham and Women's Hospital, 75 Francis St., Boston, MA 02115.

Copyright (C) 1998 by Mosby, Inc.

$0022-5223 / 98 \$ 5.00+0 \quad \mathbf{1 2 / 1 / 8 5 5 2 6}$ sterile technique and were used fresh, logistic realities necessitated the use of antibiotic treatment or preservation. The most common preservation method (cryopreservation) involves freezing in dimethyl sulfoxide and storage with liquid nitrogen. The durability of contemporary cryopreserved allograft valves is equal to or slightly better than that of conventional porcine bioprosthetic valves (50\% to $90 \%$ allograft survival at 10 to 15 years $).^{4-6}$

Nevertheless, important questions remain: (1) Are viable donor cells, including intrinsic cuspal interstitial tissue cells and endothelial cells, present at the time of implantation of cryopreserved allograft valves and do they persist over the long term? (2) Does long-term function require donor cell viability or just the intrinsic extracellular matrix? (3) To what extent is valve degeneration attributable to 
Table I. Cryopreserved aortic and pulmonic allograft valves $(n=33)$ *

\begin{tabular}{cl}
\hline \multicolumn{1}{c}{ Duration } & \multicolumn{1}{c}{ Cause of failure } \\
\hline Aortic position & \\
0 days (7) & Technical/defective valve \\
1 day (2) & Sepsis (died) \\
2 days (2) & Dehiscence (died) \\
3 days & Uncertain \\
4 days & Congestive heart failure/stenosis \\
5 days & Insufficiency \\
$2-4$ mo (3) & Infective endocarditis \\
11 mo & Insufficiency (cusp defect) \\
3 yr & Insufficiency \\
5 yr & Stenosis \\
Pulmonic position & \\
8 days & Multisystem failure \\
6 mo (2) & Stenosis \\
16 mo & Stenosis \\
$3-6$ yr (5) & Stenosis \\
$7-9$ yr (4) & Stenosis \\
\hline
\end{tabular}

*No immunosuppressive therapy; 14 additional cryopreserved/thawed valves used as controls.

immune responses? To elucidate these issues, we evaluated explanted cryopreserved allograft valves and compared them with aortic valves recovered from short-term and long-term heart transplants.

\section{Materials and methods}

We examined 33 explanted human cryopreserved allograft valves in place several hours to 9 years (11 for more than 3 years), 14 thawed but unused cryopreserved valves, and 16 aortic valves removed from orthotopic heart transplants (Tables I and II).

Of the cryopreserved allograft valve explants, 12 were aortic valves/root replacements (recipient age, 4 to 57 years; seven recipients older than 10 years of age) and 13 were right ventricle-pulmonary artery conduits (recipient age, 1 week to 44 years; 11 recipients 10 years old or less); donor ages were 2 months to 41 years. Explanted primarily because of structural deterioration, growth-related stenosis, or infection, these valves were derived from a clinical investigation by a consortium of five tissue banks in the United States performed under an Investigational Device Exemption issued by the Food and Drug Administration (24 explants) and from the surgical practice of one of us (R.A.J.) using commercial valves. ${ }^{9}$

The 16 aortic valves from heart transplants were removed at autopsy (15 specimens during 1984 through 1991, fixed 41 minutes to 24 hours after death) or retransplantation (one, fixed within 1 hour), recovered days to 4 years after transplantation, after myocardial rejection $(n=4)$, graft coronary arteriosclerosis $(n=4)$, and other causes $(n=8)$ (Table II). Transplant patients received standard triple-drug immunosuppression (prednisone, cyclosporine A [INN: ciclosporin], and azathioprine), with occasional bolus methylprednisolone sodium succinate (Solu-Medrol) or antilymphocyte antibody treatment for acute rejection episodes, as shown in Table II.
Table II. Aortic valves from transplanted hearts $(n=16) *$

\begin{tabular}{|c|c|c|c|}
\hline Duration & $\begin{array}{l}\text { Cause of death/ } \\
\text { retransplant }\end{array}$ & $\begin{array}{l}\text { No. of } \\
\text { treated } \\
\text { rejection } \\
\text { episodest }\end{array}$ & $\begin{array}{c}\text { Most recent } \\
\text { immunosuppression } \\
\text { augmentation }\end{array}$ \\
\hline \multirow[t]{2}{*}{$<3$ days (2) } & Technical & 0 & - \\
\hline & $\begin{array}{l}\text { Early graft fail- } \\
\text { ure }\end{array}$ & 0 & - \\
\hline 14 days & Rejection & 1 & $\begin{array}{l}\text { Methylprednisolone, } \\
\text { OKT3 } 2 \text { days before } \\
\text { death }\end{array}$ \\
\hline 24 days & Pneumonia & 0 & - \\
\hline \multirow[t]{2}{*}{25 days (2) } & $\begin{array}{l}\text { Mycotic aneu- } \\
\text { rysm }\end{array}$ & 0 & \\
\hline & Ischemic injury & 0 & - \\
\hline 37 days & Rejection & 1 & $\begin{array}{l}\text { Methylprednisolone, } \\
13 \text { days before death }\end{array}$ \\
\hline $2 \mathrm{mo}$ & Lymphoma & 0 & $\begin{array}{l}\text { Methylprednisolone, } \\
\text { antithymocyte globu- } \\
\text { lin } 5 \text { days before } \\
\text { death }\end{array}$ \\
\hline $2.5 \mathrm{mo}$ & $\begin{array}{l}\text { Ischemia/rejec- } \\
\text { tion }\end{array}$ & 0 & - \\
\hline $6.5 \mathrm{mo}$ & $\begin{array}{l}\text { Graft arterio- } \\
\text { sclerosis (re- } \\
\text { transplant) }\end{array}$ & 0 & - \\
\hline $7.5 \mathrm{mo}$ & Rejection & 12 & $\begin{array}{l}\text { Methylprednisolone, } \\
16 \text { days before death }\end{array}$ \\
\hline \multirow[t]{3}{*}{10 mo (3) } & Rejection & 1 & $\begin{array}{l}\text { Methylprednisolone, } \\
12 \text { days before death }\end{array}$ \\
\hline & $\begin{array}{l}\text { Graft arterio- } \\
\text { sclerosis/re- } \\
\text { jection }\end{array}$ & 1 & $\begin{array}{l}\text { Methylprednisolone, } 6 \\
\text { mo before death }\end{array}$ \\
\hline & $\begin{array}{l}\text { Graft arterio- } \\
\text { sclerosis }\end{array}$ & 0 & - \\
\hline $1 \mathrm{yr}$ & $\begin{array}{l}\text { Colon carci- } \\
\text { noma }\end{array}$ & 1 & $\begin{array}{l}\text { Methylprednisolone, } 1 \\
\text { yr before death }\end{array}$ \\
\hline $4 \mathrm{yr}$ & $\begin{array}{l}\text { Graft arterio- } \\
\text { sclerosis }\end{array}$ & 7 & $\begin{array}{l}\text { Methylprednisolone, } 4 \\
\text { mo before death }\end{array}$ \\
\hline
\end{tabular}

*Standard triple-drug maintenance immunosuppression (prednisone, cyclosporine A, azathioprine)

$\dagger$ International Society for Heart and Lung Transplantation grade 3 or greater, per Billingham ME, Cary NRB, Hammond EH, Kemnitz J, Marboe C, McAllister HA, et al. A working formulation for the standardization of nomeclature in the diagnosis of heart and lung rejection: heart rejection study group. J Heart Transplant 1990;9:587-93

Valves were fixed in $10 \%$ neutral buffered formalin; cryopreserved allograft valves $(n=5)$ for electron microscopy were fixed in $2.5 \%$ glutaraldehyde, $2 \%$ paraformaldehyde, and cacodylate buffer, $\mathrm{pH}$ 7.4. Analysis included radiography and light microscopy (stains: hematoxylin and eosin [overall morphology], Masson's trichrome [collagen], Movat pentachrome [elastin and other connective tissue elements], and von Kossa [calcification]).

Immunohistochemical studies identified endothelial cells (CD31 or von Willebrand's factor) and T- and B-lymphocyte subsets (CD45RO/UHCL-1 and CD20/L26, respectively); one valve was stained for vimentin interme- 

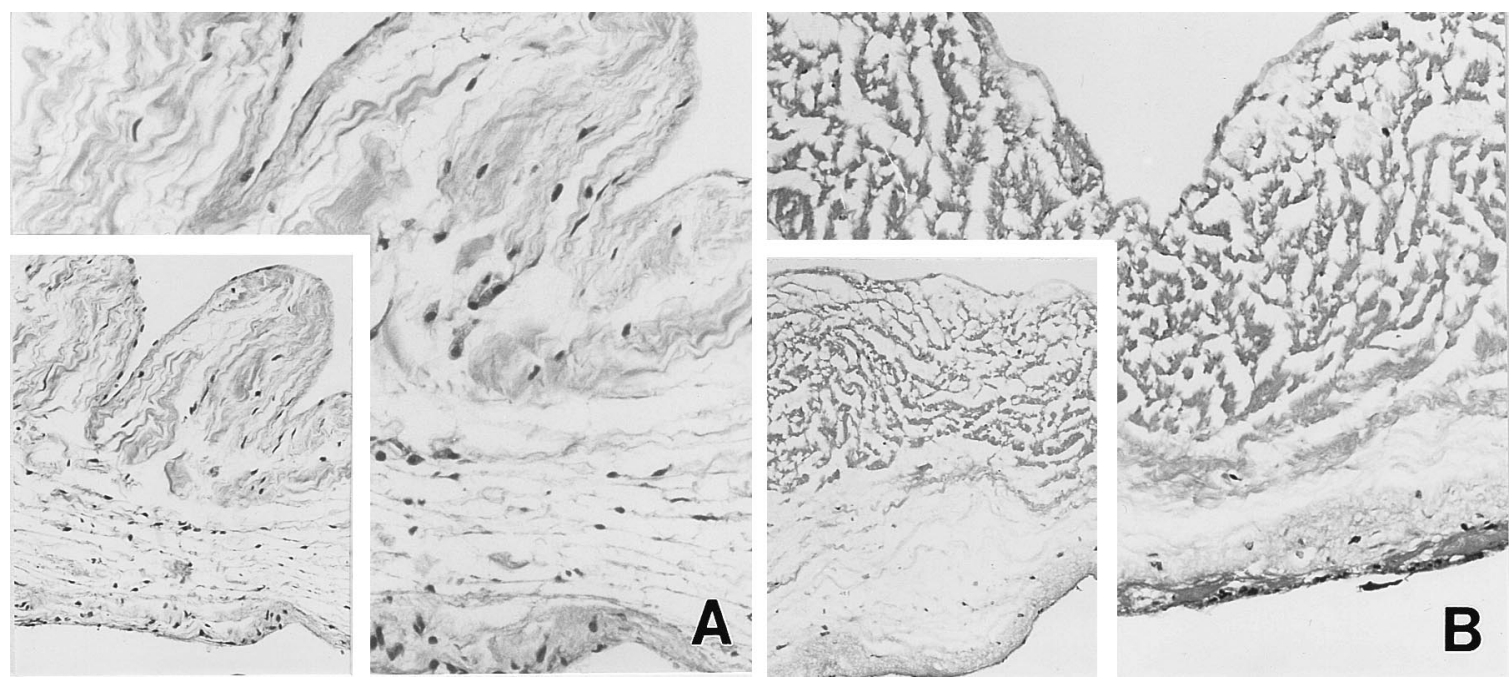

Fig. 1. Unimplanted valve and short-term explant: photomicrographs of valve cusps. A, Unimplanted valve. B, Valve removed at autopsy 2 days after implantation. Insets show corresponding low-power photomicrographs. Although the explanted valve retains a layered architecture, its interstitial cellularity is substantially diminished, and the outflow surface is flattened and less rippled than normal, suggesting early stretching of collagen toward a configuration characteristic of diastole. (Hematoxylin and eosin stain, original magnification $175 \times$; insets $90 \times$.)

diate filaments and smooth muscle cells (HHF 35). All antibodies were from Becton-Dickinson (Bedford, Mass.).

\section{Results}

Morphologic results are summarized in Figs. 1 to 6 and Table III. Results from aortic and pulmonic site explants and pediatric and adult recipients were identical, except where indicated.

Progression of cuspal and aortic/pulmonic wall changes in cryopreserved allograft valves

Unimplanted valves. Unimplanted cryopreserved and thawed allograft valves retained normal trilaminar architecture, but there was mild autolysis with smudging of the collagenous substructure, mild loss of amorphous extracellular matrix, and variable nuclear pyknosis of interstitial cells (Fig. 1, A). Elastic tissue appeared intact. Endothelial cells were focally and variably demonstrable (Fig. 6, $A$ ). Mononuclear inflammatory cells were usually minimally present (Fig. 6, B).

Short-term explants (1 to 8 days). Cryopreserved allograft valves implanted up to 8 days showed further autolysis and structural deterioration with progressive loss of interlayer demarcations, flattening of the normal outflow surface corrugations, and variably but occasionally markedly diminished interstitial tissue cells, near-complete loss of endothelial cells, and generally trivial T-lymphocytic infiltrate, without neutrophils (Fig. 1, B). Many had cuspal hematomas or superficial mural thrombi.

Intermediate-term explants (2 to 11 months). In valves implanted 2 to 11 months, there was marked deterioration of structural detail and fragmented elastic tissue with reduced staining. Cusps were flattened and thinned, with virtually no stainable interstitial tissue cells. Inflammatory cells, including neutrophils, macrophages, and T-lymphocytes, were prominent only in infective endocarditis.

Long-term explants (1 to 9 years). Gross and radiographic features of long-term cryopreserved allograft valves are illustrated in Fig. 2; histologic details are summarized in Fig. 3. Valves implanted over 1 year had flattened and thinned cusps with obliteration of the usual corrugations, indistinct layers, and no stainable interstitial or endothelial cells (Fig. 3, $A$ and $B$ ). Pannus overgrowth was generally mild and was clinically important in none. Residual elastin was present but diminished (Fig. 3, $C)$. One long-term valve had an area of noninflammatory, vimentin-positive cells in the mid-cusp area (Fig. 3, D), consistent with fibroblasts (Fig. 6, C), and a superficial smooth muscle actin-positive cell layer, suggesting origin from pannus. Lymphocytes and other inflammatory cells were sparse. Cuspal 

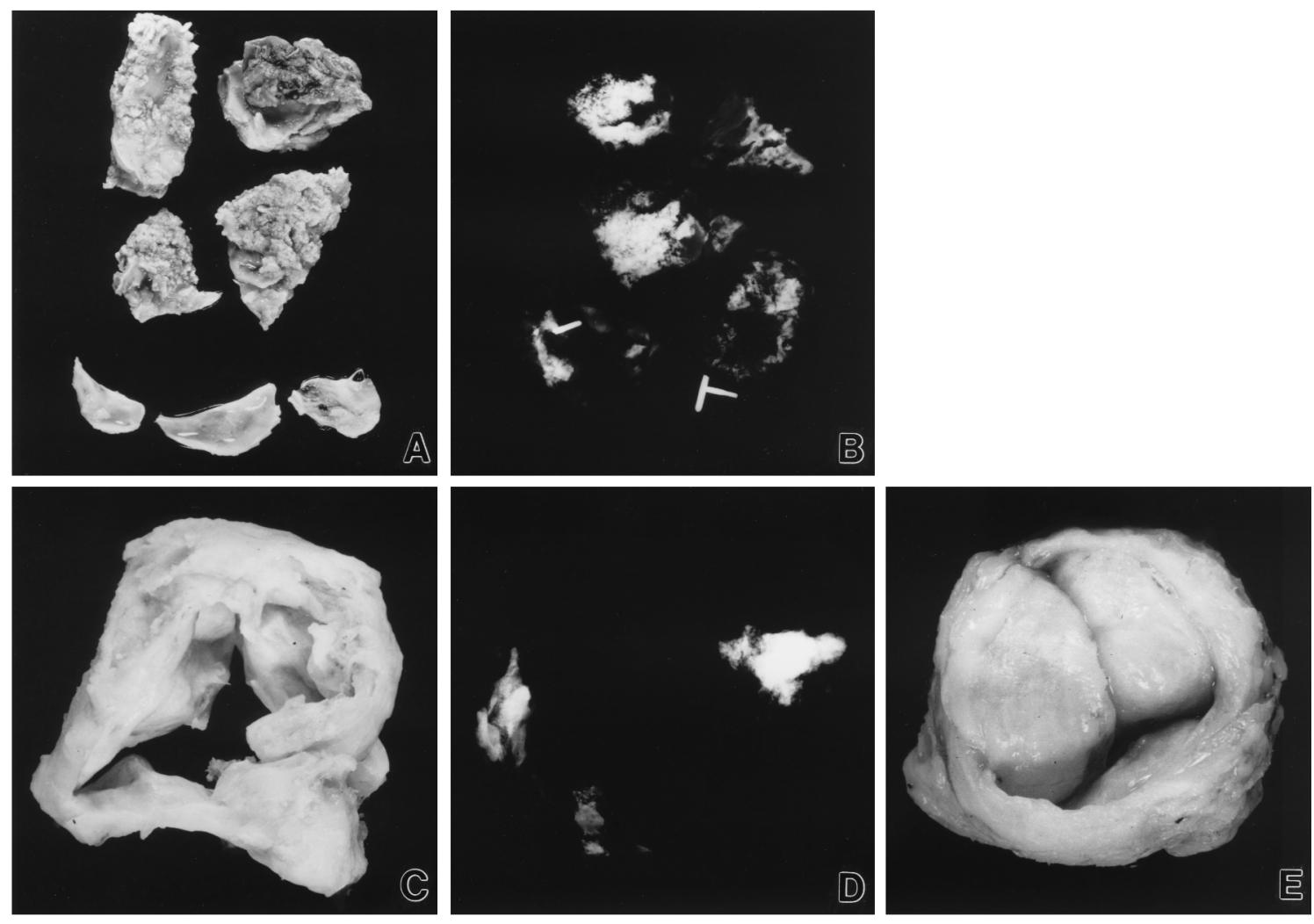

Fig. 2. Long-term explants, gross photographs, and radiographs. A, Pulmonic valve allograft and pulmonary artery conduit removed after 9 years for root stenosis from a child with repaired congenital heart disease. B, Radiograph of valve and conduit shown in A. Despite diffuse nodular mineralization of the pulmonary artery conduit wall, the cusps were soft, pliable, and noncalcified. C, Aortic allograft valve removed for aortic stenosis 4.7 years after the operation. D, Radiograph of valve shown in $\mathbf{C}$; nodular cuspal calcification is evident. E, Aortic valve allograft removed after 3 years for aortic insufficiency resulting from cuspal prolapse. No calcification was noted.

hematomas and mural thrombi were variable; cuspal calcification (occasionally nodular [Fig. 3, G]), was only focally present, despite extensive wall calcification in some explants, especially in stenotic right ventricular-pulmonary artery conduits from children.

Aortic and pulmonic wall portions of cryopreserved allograft valves generally had intact elastic lamellae but progressive loss of nuclear staining; endothelial cells were largely absent by 2 days, and extensive medial necrosis was observed as early as 3 days after implantation (Fig. 3,E). Wall calcification was variable, with occasional large nodular deposits, focal deposits suggesting cell association, and frequently prominent linear deposits involving elastin (Fig. 3, F).

Transmission electron microscopy of long-term valve cusps and walls demonstrated abundant de- generated interstitial tissue cells (Fig. 4, $A$ ) and focal microcalcifications, largely associated with cell membranes and organelles. Cuspal collagen bundles persisted but had lost their natural crimp and were markedly flattened (Fig. 4, $B$ ).

Aortic valves from orthotopic heart transplants. In contrast to the markedly abnormal structure of cryopreserved allograft valves, aortic valves from long-term cardiac transplants had essentially normal trilaminar structure, cuspal corrugations, normal and well-preserved extracellular matrices, interstitial and endothelial cells, and neither cuspal hematomas, mural thrombi, nor calcifications (Fig. 5). Mononuclear inflammatory cell infiltrates, composed primarily of T-lymphocytes, were diffuse but not prominent in most valves and were generally comparable with those seen in nonimplanted valves (Fig. 6, $B$ ). There were no 

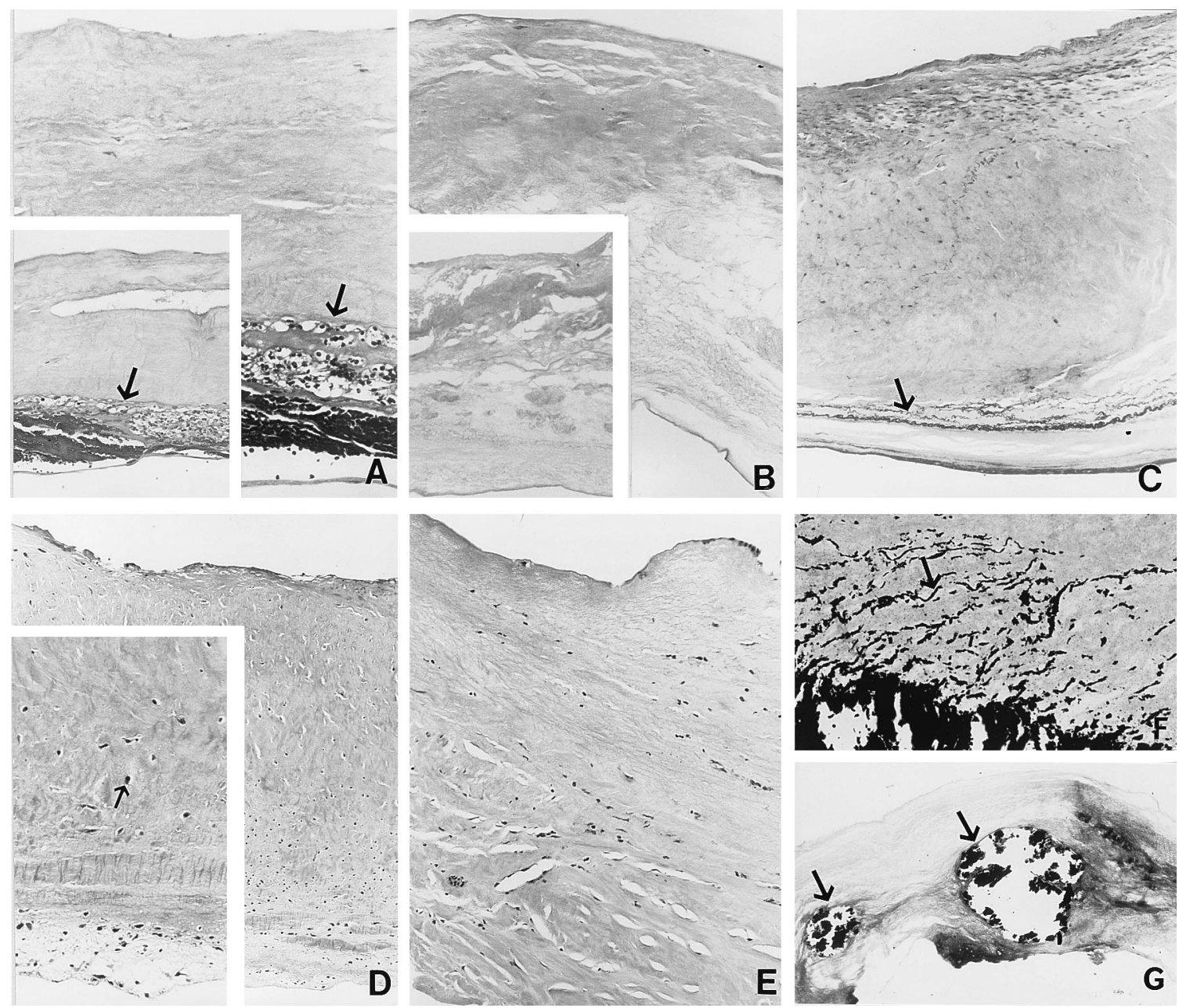

Fig. 3. Long-term explants: photomicrographs of cusps and aortic wall. A, Cusp from right-sided valve explanted after 7 years. B, Aortic valve explanted after 5 years. Insets show low-power view of the same valves. $\mathbf{A}$ and $\mathbf{B}$ show overall flattening and loss of normal layered architecture, as well as loss of endothelial and deep interstitial cells. In A, a cuspal hematoma/thrombus is present at the lower (inflow) surface (arrow). C and D, Aortic valve explanted after 3 years. In $\mathbf{C}$, the remnant layered architecture is highlighted by the staining for elastin (arrow). In $\mathbf{C}$ and $\mathbf{D}$ there is patchy cuspal interstitial cellularity. A representative stained cell nucleus is highlighted by an arrow in D. E, Aortic wall remnant of valve shown in $\mathbf{B}$, demonstrating replacement of normal aortic wall architecture by fibrosis. F, Nodular calcification of aortic wall portion of right-sided pulmonic valve and pulmonary artery allograft, with prominent calcification along the residual pulmonary artery elastin (arrow). G, Cuspal calcific nodules (arrows). A, B, D, and E, Hematoxylin and eosin stain; F and G, Stained with von Kossa's reagent (calcium phosphates are black). Magnifications: A, B, inset D, E, and F, original magnifications $175 \times$; inset A, B, C, and D, $90 \times$. C, Stained with Movat pentachrome stain (elastin black).

differences in valves from allografts failing as a result of severe parenchymal rejection or graft arteriosclerosis regardless of immunosuppression regimens (Fig. 6, $D$ to $G$ ) nor in valves from allografts having as many as 12 rejection episodes. Significantly, these results suggest no valvular destruction or any other deleterious morphologic effect resulting from inflammation.

\section{Discussion}

This study documents and extends our preliminary data on the morphologic features of explanted cryopreserved aortic and pulmonic valves ${ }^{7,8}$ and includes comparisons with aortic valves obtained from orthotopic heart transplants.

Cellular viability. A theoretic advantage of cryopreserved allograft valves over glutaraldehyde-fixed 


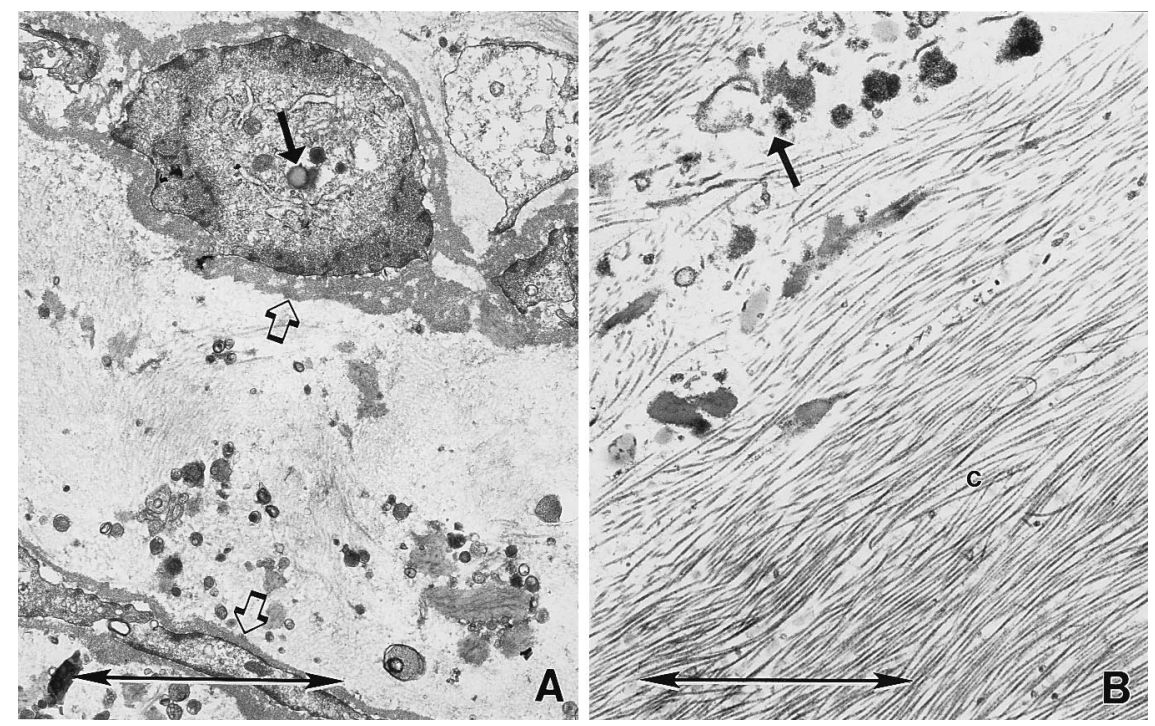

Fig. 4. Long-term explants; ultrastructure. A, Cellular remnants (open arrows) with focal microcalcification (solid arrow) are present diffusely throughout the cuspal connective tissue matrix, despite the absence of cellular staining on routine histologic stains. B, Dense residual collagen (c) and cell remnants (arrow) in long-term explant. The collagen has some degradation of structure and marked flattening characteristic of the diastolic configuration; wavy crimp typical of a relaxed normal valve is absent. Stained with uranyl acetate and lead citrate. Double-headed arrow in lower left $=3 \mu \mathrm{m}$. Original magnification 10,000 $\times$.

bioprostheses is maintenance of interstitial and endothelial cell viability, potentially enabling continuous remodeling, growth, and thromboresistance. However, consistent with other recent studies, 9,10 our results document a consistent and marked paucity of viable cuspal cells in cryopreserved allograft valves implanted for any time over 2 months. Although the presence of nuclear staining does not necessarily prove that cells are viable or healthy, absence of nuclear staining by routine histologic examination or fragmentation observed by electron microscopy is generally construed to indicate absence or death of preexisting cells.

The lack of viable cells reflects the cumulative damage of ischemia before and after harvest, cryopreservation, thawing, and implantation trauma. Although cell injury during ischemia and cryopreservation of allograft valves is well documented, ${ }^{11,12}$ some workers report long-term survival of certain cellular elements in both experimental systems and explanted allografts from human recipients. ${ }^{2,13-15}$ In one study, viable fibroblasts were routinely cultured from explanted cryopreserved allografts. ${ }^{2}$ Some of these may derive from recipient pannus, as our identification of vimentin and smooth-muscle actinpositive cells in one long-term implant suggests. Nevertheless, the finding by chromosomal analysis of donor-derived fibroblasts cultured from one cryopreserved allograft after 9 years indicates that occasional donor fibroblasts may survive and possibly proliferate in some optimally preserved valves (i.e., minimal ischemia and cryopreservation-induced damage). ${ }^{2}$ However, it is unlikely that a limited population of viable cells will contribute to anatomically appropriate cellularity capable of functional matrix remodeling.

Allograft valve durability: Role of collagen and calcification. The absence of donor valve fibroblasts capable of contributing to remodeling of the extracellular matrix implies that durability of the cryopreserved allograft valve is dependent predominantly on the quality of the original collagenous skeleton. Indeed, ongoing degeneration of the extracellular matrix likely accounts for the modest rate of progressive dysfunction (predominantly regurgitation) in the aortic site in adults. Our ultrastructural results suggest that the collagen network derived from the donor valve is largely intact, thereby providing the structural basis for long-term performance. It follows that modest delays from donor death to graft harvest may have little effect on this relatively autolysis-resistant collagenous skeleton. Indeed, allografts implanted in sheep showed no functional or pathologic differences among valves 

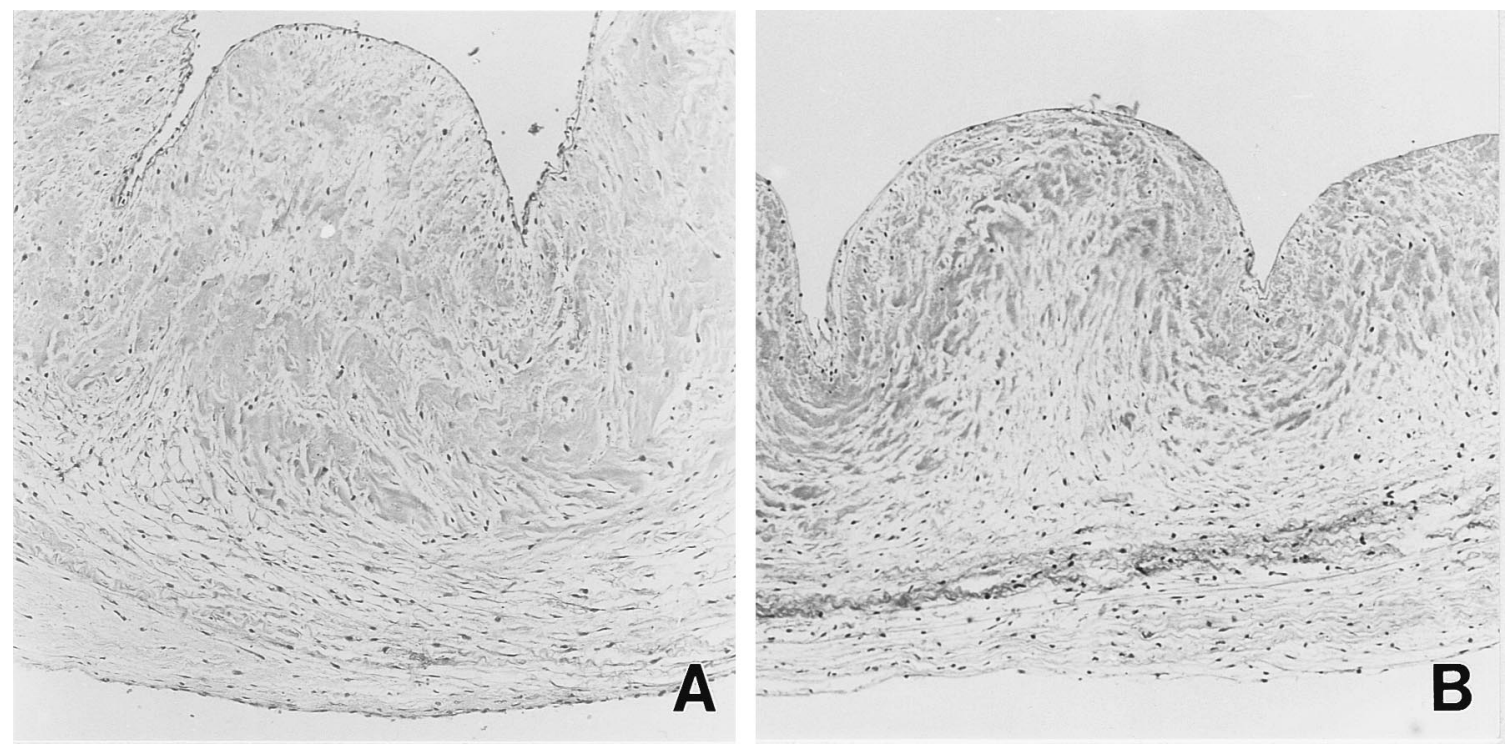

Fig. 5. Photomicrographs of cusps from valves from orthotopic heart transplants. A, Aortic valve removed from patient dying of fulminant acute myocardial rejection 7.5 months after the operation. This patient had had 12 treatable rejection episodes over 7 months; the last augmentation of immunosuppression was with methylprednisolone sodium succinate (Solu-Medrol) 16 days before death. B, Aortic valve removed from patient dying of graft coronary arteriosclerosis 4 years after heart transplantation; last augmentation of immunosuppression was with methylprednisolone 4 months before death. Both valves show the expected layered architecture outflow surface rippling characteristic of the normal valve in the relaxed state, as well as a normal complement of interstitial and endothelial cells. (Hematoxylin and eosin, original magnifications $90 \times$.)

removed up to 48 hours post mortem from sheep cadavers maintained at $4^{\circ} \mathrm{C}^{16}$ and between cryopreserved and fresh antibiotic-treated valves preserved at $4^{\circ} \mathrm{C}$ for up to 6 days. ${ }^{17}$ This suggests possible expansion of the donor pool for allografts by extending current limits on postmortem interval.

Calcification in cryopreserved allograft valves was most prominent in the pulmonary arterial or aortic walls, consistent with prior studies showing extensive wall calcification as a major failure mode for cryopreserved allograft valves in the pulmonary circulation of children ${ }^{18}$; cuspal calcification was substantially less frequent. As with other cardiovascular calcification processes, ${ }^{19,20}$ deposits appeared to originate in residual nonviable cells, their fragments, elastic tissue, or collagen. The reason(s) for less calcification of cryopreserved allograft valves relative to glutaraldehyde-fixed porcine bioprosthetic valve cusps is uncertain. We hypothesize that allograft valves have more extensive autolysis during processing, intraoperative preparation, and possibly after implantation, and that autolysis may reduce the calcifiability of the residual cellular debris.
Contribution of the immune response to allograft deterioration. Although cryopreserved allograft valves may induce a detectable donor HLA-specific humoral response ${ }^{21-23}$ and may be associated with unexplained postoperative fever, ${ }^{24}$ there is no evidence that these reactions contribute to valve disease. Progressive loss of cuspal cellular viability and cumulative changes in the extracellular matrix occurred in the absence of significant mononuclear inflammatory cell infiltrates, despite lack of immunosuppression and unmatched HLA or blood groups. Neutrophilic infiltrates, anticipated for antibody-mediated injury, were also notably absent. Significant inflammation was seen only in endocarditis. Thus our results provide no evidence that cell-mediated immune injury causes pathologic changes in the cryopreserved allograft valve; indeed, they suggest that immune responses are noncontributory. Inasmuch as cryopreserved allograft valves were examined at many postoperative intervals, including the first week (during which significant histologic deterioration occurs), transient occult immune injury is unlikely. However, it remains possi- 

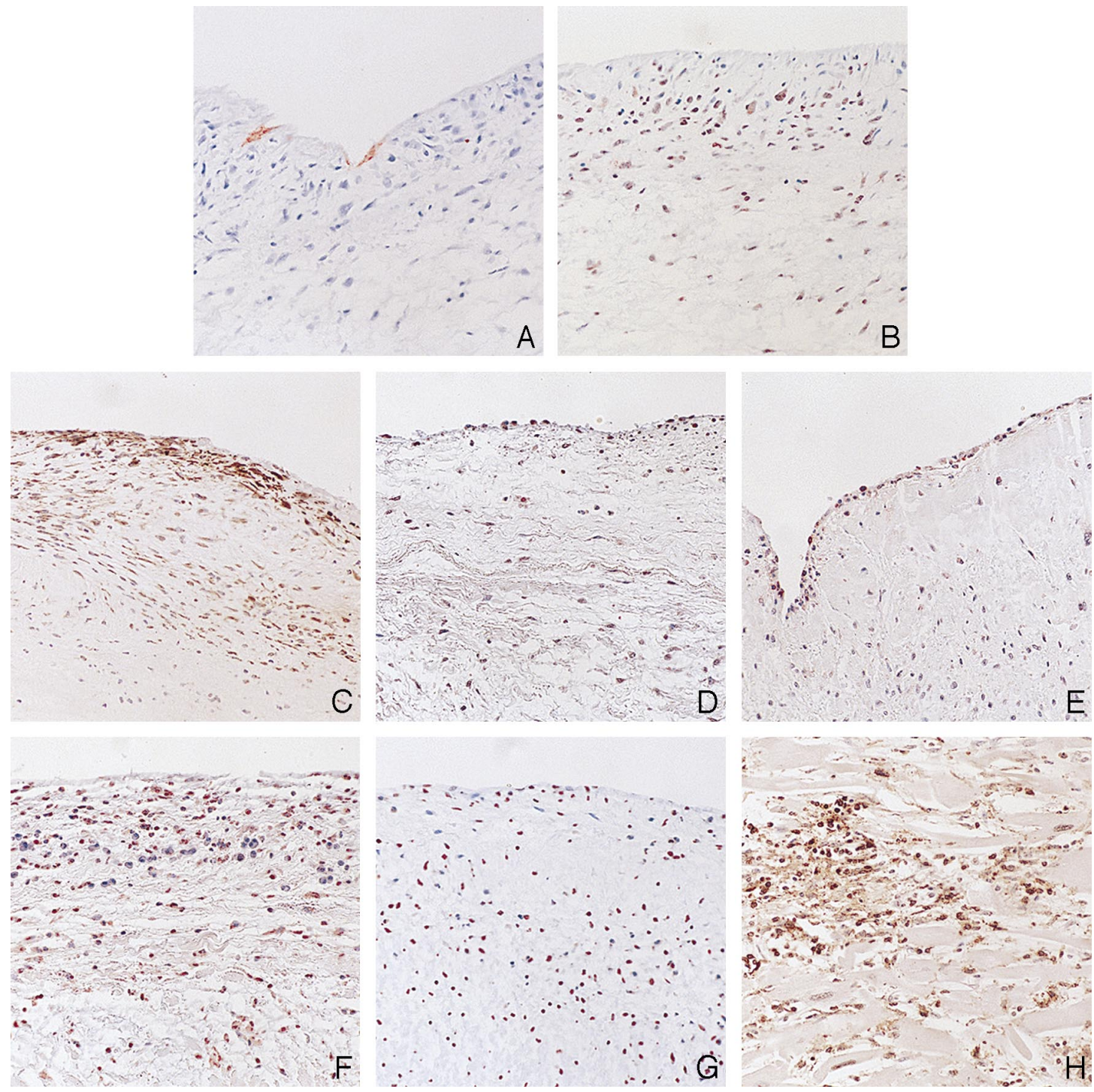

Fig. 6. Immunohistochemical staining results. A, Von Willebrand's factor staining of unimplanted cusp demonstrating sparse preservation of endothelial cells. B, CD45RO immunohistochemical staining of unimplanted valve demonstrating a mild diffuse infiltrate of mononuclear inflammatory cells (T-lymphocytes and macrophages). C, Immunohistochemical staining of valve cusp shown in Fig. 2, C and $\mathbf{D}$ for vimentin showing positivity of interstitial cells near the inflow surface, suggesting that these are mesenchymal cells derived from recipient pannus formation. D, T-cell $(\mathrm{CD} 45 \mathrm{RO})$ staining of valve removed from heart transplant patient who died of a technical complication 2 days after the operation. E, T-cell (CD45RO) staining of aortic valve from heart transplant patient dying 2.5 months after the operation of complications of perioperative myocardial ischemic injury. F, T-cell (CD45RO) staining of aortic valve of heart transplant from patient who required retransplantation 6.5 months after transplantation for graft coronary arteriosclerosis. G, T-cell (CD45RO) staining of aortic valve from heart transplant patient who died 7.5 months after the operation of fulminant acute myocardial rejection (also shown in Fig. 5, A). H, T-cell (CD45RO) staining of myocardium from heart whose aortic valve is represented in $\mathbf{G}$. These immunohistochemical studies demonstrate that T-cells are sparse in aortic valves of heart transplants in the early postoperative period and although present in greater density thereafter do not appear to correlate with myocardial infiltrates in acute myocardial rejection. Despite the presence of T-cell infiltrates in the valve from a heart necessitating retransplantation for graft arteriosclerosis (F), there is no evidence of intimal proliferation characteristic of the coronary arterial lesion (see Fig. 5, B). (All original magnifications $175 \times$.) 
Table III. Morphology of allograft cardiac valves

\begin{tabular}{|c|c|c|c|c|c|}
\hline & \multicolumn{4}{|c|}{ Cryopreserved } & \multirow{2}{*}{$\begin{array}{c}\text { Cardiac transplant: } \\
0 \text { days }-4 y r\end{array}$} \\
\hline & Unimplanted & 0-8 days & $2-11 \mathrm{mo}$ & $1-9 y r$ & \\
\hline Number of specimens & 14 & 15 & 6 & 12 & 16 \\
\hline Trilaminar architecture & ++ & ++ & - & - & +++ \\
\hline Stainable connective tissue cells & ++ & $+/++$ & - & - to $+\dagger$ & +++ \\
\hline Lymphocytic infiltrate (T-cells) & - to + & $-/+$ & - to $+++^{*}$ & - to + & $+/++$ \\
\hline Intact endothelium & $-/+$ & $-1+$ & - & - & $+/++$ \\
\hline Intimal hyperplasia/pannus & - & - & - & $+1-$ & - \\
\hline Cuspal hematoma/thrombus & - & $-/+$ & $+/++$ & - to ++ & - \\
\hline \multicolumn{6}{|l|}{ Calcification } \\
\hline Cusps & - & - & - & - to + & - \\
\hline Walls & - & - & - & - to +++ & $-/+$ \\
\hline
\end{tabular}

Cellularity and other morphologic measures of the explanted valves semi-quantified as: $-=$ not present; $+=$ mild/minimal; $++=$ moderate; and +++ $=$ severe $/$ marked.

* Substantial only in those valves with endocarditis.

$\dagger$ Predominantly associated with pannus.

ble that immunologically mediated injury occurred undetected in the temporal window between 9 days and 2 months after implantation (specimens unavailable). ${ }^{23}$

The lack of morphologic evidence of immunemediated injury has several implications. Foremost, these data suggest no rational basis for the use of immunosuppression in improving the durability of cryopreserved allograft valves. Inasmuch as endothelial cells, smooth muscle cells, and fibroblasts are in fact variably capable of eliciting an immune response, ${ }^{25-27}$ the lack of immune injury may be attributable in part to loss of cell viability. Indeed, immunologic reactivity and allograft valve durability are affected by preservation methods. ${ }^{28,29}$ However, the absence of immune-mediated pathologic changes even in viable valves from heart transplants suggests an intrinsic resistance to immune injury (see below).

Aortic valves from orthotopic heart transplants. The present study shows that aortic valves from both short-term and long-term heart transplants have essentially normal gross and microscopic structure and intrinsic cellularity, in agreement with another recent report. ${ }^{30}$ The valves we studied included those from patients with as many as 12 previous rejection episodes and from fatal myocardial rejection in which the allograft response had overwhelmed immunosuppression. Valves from transplants were also free of degenerative features, including calcification and the intimal thickening characteristic of graft arteriosclerosis. Moreover, the mild T-lymphocytic infiltrate seen in valves from allograft hearts was comparable with that in normal aortic valves removed at autopsy (i.e., unimplanted cryopreserved allograft valves in this study).

It is uncertain why valves in heart transplants are not apparently damaged by rejection. We hypothesize several possible factors: (1) the endothelium overlying valves has a different level of histocompatibility and adhesion molecule expression than that of the myocardial microvasculature or (2) high flow over the valve surface (relative to slower flow within the myocardium) reduces significant mononuclear inflammatory cell binding. Moreover, with significantly lower metabolic demand than myocardium, valves in heart transplants should have less ischemic injury during transplantation with consequently less ischemia-induced up-regulation of adhesion molecules.

\section{Conclusions}

Cryopreserved allograft heart valves have early cellular autolysis and exhibit severe degeneration after implantation, with disruption of normal architectural detail, loss of endothelial and interstitial cells, and variable mild inflammatory cellularity. They are unlikely to have any significant capacity to grow, remodel, or exhibit active metabolic functions. Their durability seems primarily related to the largely preserved extracellular matrix. That 33 explanted cryopreserved allograft valves deriving from five different tissue banks and one commercial source showed similar results suggests that our results are broadly representative. In contrast, aortic valves of transplanted hearts maintain near-normal overall architecture and cellularity. No evidence for immune-mediated dysfunction was found in either type of aortic valve allograft. 
We are grateful for the efforts and cooperation of the many cardiac surgeons and their colleagues who provided specimens and clinical data and for the assistance and partial financial support of this study by a consortium of cryopreserved allograft heart valve processing facilities (including the American Red Cross Tissue Service, Los Angeles, California, LifeNet Transplant Services, Virginia Tissue Bank, Virginia Beach, Virginia, Alabama Tissue Center, Birmingham, Alabama, United CryoInstitute, Chicago, Illinois, and the Oregon Tissue Bank, Portland, Oregon, for which we served as the core pathology laboratory). We thank the members of the Brigham and Women's Hospital Cardiac Transplant Service for their efforts in the clinical management of the heart transplant patients reported in this study and particularly Ms. Colleen Smith for her assistance in retrieving patient rejection and immunosuppression histories. We are also grateful to Sara Murray, Elena Rabkin, and Helen Shing for technical assistance and to Claudia Davis for typing and editing the manuscript.

\section{REFERENCES}

1. Ross D. Homograft replacement of the aortic valve. Lancet 1962;2:487.

2. O’Brien M, Stafford E, Gardner M, Pohlner P, McGiffin D. A comparison of aortic valve replacement with viable cryopreserved and fresh allograft valves with a note on chromosomal studies. J Thorac Cardiovasc Surg 1987;94:812-23.

3. Tuna IC, Orszulak TA, Schaff HV, Danielson GK. Results of homograft aortic valve replacement for active endocarditis. Ann Thorac Surg 1990;49:619-24.

4. Kirklin JK, Smith D, Novick W, Naftel DC, Kirklin JW, Pacifico $\mathrm{AD}$, et al. Long-term function of cryopreserved aortic homografts. J Thorac Cardiovasc Surg 1993;106:154-66.

5. Matsuki O, Robles A, Gibbs S, Bodnar E, Ross D. Long-term performance of 555 aortic homografts in the aortic position. Ann Thorac Surg 1988;46:187-91.

6. Grunkemeier GL, Bodnar E. Comparison of structural valve failure among different "models" of homograft valves. J Heart Valve Dis 1994;3:556-60.

7. Mitchell RN, Jonas RA, Schoen FJ. Structure-function correlations in cryopreserved allograft cardiac valves. Ann Thorac Surg 1995;60:S108-13.

8. Schoen FJ, Mitchell RN, Jonas RA. Pathologic considerations in cryopreserved allograft heart valves. J Heart Valve Dis 1995;4:S72-6.

9. Armiger LC. Viability studies of human valves prepared for use as allografts. Ann Thorac Surg 1995;60:S118-21.

10. Goffin YAH, de Douveia RH, Szombathelyi T, Toussaint MJM, Gruys E. Morphologic study of homograft valves before and after cryopreservation and after short-term implantation in patients. Cardiovasc Pathol 1997;6:35-42.

11. Lang S, Giordano M, Cardon-Cardo C, Summers B, StaianoCoico L, Hajjar D. Biochemical and cellular characterization of cardiac valve tissue after cryopreservation or antibiotic preservation. J Thorac Cardiovasc Surg 1994;108:63-7.

12. Hu J-F, Gilmer L, Hopkins R, Wolfinbarger L. Effects of antibiotics on cellular viability in porcine heart valve tissue. Cardiovasc Res 1989;23:960-4.

13. Wheatley D, McGregor C. Post implantation viability in canine allograft heart valves. Cardiovasc Res 1977;11:78-85.
14. Angell W, Oury J, Lamberti J, Koziol J. Durability of the viable aortic allograft. J Thorac Cardiovasc Surg 1989;98:4856.

15. Girinath M, Gavin J, Strickett M, Barratt-Boyes B. The effects of antibiotics and storage on the viability and ultrastructure of fibroblasts in canine heart valves prepared for grafting. Aust N Z J Surg 1974;44:170-2.

16. Kadoba K, Armiger L, Sawatari K, Jonas RA. Influence of time from donor death to graft harvest on conduit function of cryopreserved aortic allografts in lamb. Circulation 1991; 84(Suppl):III100-11.

17. Jonas RA, Ziemer G, Britton L, Armiger LC. Cryopreserved and fresh antibiotic-sterilized valved aortic homograft conduits in a long-term sheep model. J Thorac Cardiovasc Surg 1988;96:746-55.

18. Cleveland DC, Williams WG, Razzouk AJ, Trusler GA, Rebeyka L, Duffy Z, et al. Failure of cryopreserved homograft valved conduits in the pulmonary circulation. Circulation 1992;86(Suppl):II150-3.

19. Schoen FJ, Hirsch D, Bianco RW, Levy RJ. Onset and progression of calcification in porcine aortic bioprosthetic valves implanted as orthotopic mitral valve replacements in juvenile sheep. J Thorac Cardiovasc Surg 1994;108: 880-7.

20. Anderson HC. Mechanisms of pathologic calcification. Rheumat Dis Clin North Am 1988;14:303-19.

21. Fishlein T, Schütz, Haushofer M, Frey R, Uhlig A, Detter C, et al. Immunologic reaction and viability of cryopreserved homografts. Ann Thorac Surg 1995;60:S122-6.

22. Smith JD, Ogino H, Hunt D, Laylor RM, Rose ML, Yacoub MG. Humoral immune response to human aortic valve homografts. Ann Thorac Surg 1995;60:S127-30.

23. Hogan P, Duplock L, Green M, Smith S, Gall KL, Frazer IH, et al. Human aortic valve allografts elicit a donor-specific immune response. J Thorac Cardiovasc Surg 1996;112:1260-6.

24. Shapira OM, Fonger JD, Reardon K, Shemin RJ. Unexplained fever after aortic valve replacement with cryopreserved allografts. Ann Thorac Surg 1995;60:S151-5.

25. Gonzalez-Lavin L, Bianchi J, Graf D, Amini S, Gordon CI. Degenerative changes in fresh aortic root homografts in canine model: evidence of an immunologic influence. Transplant Proc 1988;20:815-9.

26. Lupinetti FM, Tsai TT, Kneebone JM, Bove EL. Effect of cryopreservation on the presence of endothelial cells on human valve allografts. J Thorac Cardiovasc Surg 1993;106: 912-7.

27. Salomon RN, Friedman GB, Callow AD, Payne DD, Libby P. Cryopreserved aortic homografts contain viable smooth muscle cells capable of expressing transplantation antigens. J Thorac Cardiovasc Surg 1993;106:1173-80.

28. Mulligan MS, Tsai TT, Kneebone JM, Ward PA, Lupinetti FM. Effects of preservation techniques on in vivo expression of adhesion molecules by aortic valve allografts. J Thorac Cardiovasc Surg 1994;107:717-23.

29. Ketheesan N, Kearney JN, Ingham E. The effect of cryopreservation on the immunogenicity of allogeneic cardiac valves. Cryobiology 1996;33:41-53.

30. Valente M, Faggian G, Billingham ME, Talenti E, Calabrese F, Casula R, et al. The aortic valve after heart transplantation. Ann Thorac Surg 1995;60:S135-40. 